\title{
An Experiential Cooking and Nutrition Education Program Increases Cooking Self-Efficacy and Vegetable Consumption in Children in Grades 3-8
}

\author{
Elizabeth Jarpe-Ratner, $\mathrm{MPH}^{1, \dagger}$; Stephanie Folkens, $\mathrm{BA}^{2}$; Sonika Sharma, $\mathrm{MS}^{2}$; \\ Deborah Daro, $\mathrm{PhD}^{3}$; Neilé K. Edens, $\mathrm{PhD}^{2}$
}

\begin{abstract}
Objective: Evaluate the effect of a community-based, experiential cooking and nutrition education program on consumption of fruits and vegetables and associated intermediate outcomes in students from low-income families.

Design: Quasi-experimental program evaluation by pre-post survey of participating students and their parents.

Setting: Underserved elementary and middle schools in Chicago.

Participants: Students $(n=271 ; 65 \%$ girls, 44\% Hispanic, 32\% African American; 94\% eligible for free/ reduced price lunch) in grades 3-8 selected by school staff to participate by variable inclusion criteria. 59\% of students who applied returned both pre- and post-surveys.

Intervention(s): Ten-week (2 h/wk) chef-instructor-led program held in cafeteria kitchens after school. Main Outcome Measure(s): Changes in student nutrition knowledge, cooking self-efficacy, fruit and vegetable liking and consumption, and communication to family about healthy eating.

Analysis: Changes from beginning to end of program were analyzed with paired $t$ test. Results were considered significant at $P<.05$.

Results: Increased nutrition knowledge score from 0.6 to 0.8 , cooking self-efficacy score from 3.2 to 3.6, and vegetable consumption score from 2.2 to 2.4 (all $P<.05$ ). Increased score for communication about healthy eating $(4.1$ to $4.4 ; P<.05) 6$ months after the end of the course.

Conclusions and Implications: Experiential cooking and nutrition education programs led by chef-instructors may be effective ways to improve nutrition in low-income communities.

Key Words: elementary school, middle school, vegetable preference, vegetable liking, food preference, cooking (J Nutr Educ Behav. 2016;48:697-705.)
\end{abstract}

Accepted July 27, 2016. Published online August 26, 2016.

\section{INTRODUCTION}

The epidemic of pediatric obesity has focused both research and policy attention on determinants of energy balance and diet quality in children. ${ }^{1,2}$ Dietary patterns that are energy- and fat-dense but depleted of high-fiber foods may be predictive of later obesity in children. ${ }^{3}$ Healthier dietary patterns result when children consume recommended amounts of fruits, vegetables, and whole grains. However, poor compliance with dietary guidelines for these

\footnotetext{
${ }^{1}$ School of Public Health, University of Illinois, Chicago, IL

${ }^{2}$ Common Threads, Austin, TX

${ }^{3}$ Chapin Hall, University of Chicago, Chicago, IL

Conflict of Interest Disclosure: The authors' conflict of interest disclosures can be found online with this article on www.jneb.org.

${ }^{\dagger}$ Ms Jarpe-Ratner was affiliated with the University of Chicago at the time this study was completed.

Address for correspondence: Neilé K. Edens, PhD, Common Threads, 3811 Bee Cave Rd, Ste 108, Austin, TX 78746; Phone: (512) 879-3376; E-mail: nedens@.commonthreads.org (C2016 The Authors. Published by Elsevier, Inc. on behalf of the Society for Nutrition Education and Behavior. This is an open access article under the CC BY-NC-ND license (http://creativecommons.org/licenses/by-nc-nd/4.0/).

http://dx.doi.org/10.1016/j.jneb.2016.07.021
}

Journal of Nutrition Education and Behavior • Volume 48, Number 10, 2016

foods has been well documented in children. ${ }^{4}$ Despite numerous campaigns to promote fruit and vegetable consumption, there was no improvement in vegetable consumption in US children on a national level from 2003 to $2010 .{ }^{5}$ In addition, vegetable consumption decreased slightly but significantly during that period in African American and Hispanic children. ${ }^{5}$ Fruit intake increased slightly in children from 2003 to 2010, except in children from relatively low-income families (income $<130 \%$ of the poverty level). ${ }^{5}$ It was reported that on a given day only $11 \%$ of children aged 6-11 years eat dark green vegetables and only $36 \%$ consume citrus, melons, or berries. ${ }^{6}$

Frequent family meals increase children's intake of fruits, vegetables, grains, and calcium-rich foods, reduce children's intake of foods with high 
caloric but low nutrient density, ${ }^{7}$ and may protect against obesity later in life. ${ }^{8}$ This latter effect may be mediated in part by cooking at home because vegetables prepared at home are lower in sodium and calories than those prepared away from home ${ }^{9}$ and meals prepared at home contain fewer calories, a lower proportion of fat calories, and more fiber, calcium, and iron per calorie than foods prepared away from home. ${ }^{10}$ Nevertheless, Centers for Disease Control and Prevention statistics showed that a significant proportion of children (eg, 35\% in Illinois) do not eat family meals on $\geq 4$ days of the week. ${ }^{11}$

The home food environment, as measured by the availability and accessibility of fruits and vegetables, predicts the diet quality of children. ${ }^{12-14}$ Parents can have a strong positive influence on their child's eating habits by making fruits and vegetables available, modeling consumption, and voicing support for healthy behaviors. ${ }^{15}$ Children also contribute to the healthy home environment by requesting fruits and vegetables in the home, grocery shopping with parents, and asking to have their favorite fruits and vegetables within reach. ${ }^{15,16}$ These studies ${ }^{12-16}$ indicated that children and parents interact to create the family food environment and that cooking meals at home may improve diet quality.

To improve the home food environment and childhood nutrition, nutrition education programs aim to increase child liking for fruits and vegetables, cooking at home, and communication from the child to the family about healthy eating. Fruit and vegetable liking is important because preference for vegetables predicted lower body mass index (BMI) in African American children. ${ }^{17}$ The relevance of cooking at home was established by the finding that among participants in the Supplemental Nutrition Assistance Program, frequent cooking at home predicted greater vegetable consumption, ${ }^{18}$ which suggests that increasing the frequency of cooking at home may improve nutritional status. Ideally, nutrition education programs will teach children how to identify and select appropriate amounts of healthy foods and include opportunities for participants to taste and enjoy healthy foods. ${ }^{19}$ Combined hands-on cooking and nutrition education programs have been demonstrated to improve children's preference for fruits and vegetables $^{20,21}$ and feelings of cooking selfefficacy $^{22}$ and increase the frequency with which children help make dinner at home. ${ }^{23}$ It was hypothesized that a school-based, integrated cooking and nutrition education program facilitated by trained chef-instructors paired with technical support from program managers would be an effective method to improve students' fruit and vegetable exposure, liking, and consumption and that effects would be accompanied by increases in nutrition knowledge, cooking self-efficacy, and communication to the family about healthy eating. They also hypothesized that parents would confirm these changes in the home food environment, and that the effects would persist for at least 6 months after the end of the program.

\section{METHODS}

\section{Study Design}

This was a 1-year (school year 20112012) evaluation of a communitybased nutrition and cooking education program (Common Threads) that has been offered continuously since $2003 .{ }^{24}$

\section{Participants and Recruitment}

The evaluation included 17 elementary schools and 1 middle school in Chicago. High-poverty schools (at least $80 \%$ of students eligible for free or reducedprice lunch) were enrolled if they were willing and able to accept the program. School staff selected students to apply to participate in the program using their own criteria (variable inclusion criteria). Some schools allowed students to participate as a reward for good behavior whereas others chose students in need of a hands-on, active program. Application packets were distributed to selected students to take home to parents for review and signature. Application packets contained program consent forms, survey consent forms, media release forms, and the parent pre-survey. A total of 462 students applied to participate in the study; 271 students who completed the application, program, and pre- and post-surveys were included in the analysis. Students were excluded from the analysis if they did not complete both a pre-survey and post-survey. Surveys were missing if students missed the first or last class. Attendance data were not collected. A subset of students' parents $(n=257)$ participated in the evaluation. The study was approved by Chicago Public Schools Research Review Board and the University of Chicago Institutional Review Board.

\section{Intervention}

Students participated in a 10-week afterschool cooking and nutrition education course taught at each of the 17 schools in the school kitchen by professional chef-instructors who went through standardized training ( 2 hours) by Common Threads staff and were issued the printed curriculum upon completion of training. The course was designed to focus primarily on cooking skills; it used culinary instruction to impart lessons in nutrition and cultural awareness. Because of this focus on cooking, chef-instructors were considered to be best qualified to teach and model professional cooking skills and instill enthusiasm for cooking and fresh food. Chefinstructors were supported by Common Threads program managers who facilitated interactions and scheduling with the schools, advised chef-instructors on management of volunteers and schoolchildren, and reviewed recipe adjustments necessitated by varying availability of ingredients to ensure that they were aligned with principles of good nutrition. With rare exceptions, each chef-instructor taught at only 1 school. Chef-instructors were assisted by volunteers (teachers or other school staff) to achieve a maximum student to adult ratio of 5:1. The course consisted of 102 -hour sessions taught after school in a single semester. The detailed, standardized course curriculum, including materials for both chef-instructors and students, was written by Common Threads staff members, 1 of whom was a certified teacher; the other was a trained chef. The curriculum was reviewed by a registered dietitian. Each lesson consisted of 30 minutes of lecture and discussion of nutrition principles and cultural awareness, 75 minutes of instruction in culinary skills and hands-on meal preparation, and 15 minutes of meal sharing and conversation. Every lesson presented content and exercises designed to teach the recommended composition of a healthy meal, ie, that half of the plate should contain 
fruits and vegetables. Each of the 10 well-balanced meals prepared by students included fruits and/or vegetables. Table 1 shows the content and learning objectives of each lesson. Students were formed into teams, which were maintained throughout the course, to practice cooking skills and prepare the meal at each lesson. Recipes were developed to be affordable and flexible, and to illustrate nutrition principles aligned with 2010 US Dietary Guidelines for Americans. Students were encouraged by the chef-instructors to tell their families about healthy eating and to cook at home. Parents were encouraged to attend the final class and eat with their child.

\section{Instruments, Measures,} Procedures, and Data Analysis

The effect of the program was assessed on students and parents with a quasiexperimental pre-post survey design. Written surveys were administered to the students in the first and last lesson of the course. The survey was developed by adapting questions from publicly available sources to collect demographic data and test nutrition knowledge, exposure to and liking of fruits and vegetables, number of times fruits and vegetables were consumed the previous day, ${ }^{25}$ cooking skills, ${ }^{26}$ and family communication about healthy eating and other behaviors ${ }^{27}$ (Table 2). The survey was piloted before use in the evaluation and refined between fall and spring semesters by omitting questions that were judged to be redundant or uninformative and adding questions about helping at home and general self-efficacy. Only data from questions administered on both fall and spring surveys are reported. Fall and spring data were pooled for analysis, except as noted subsequently.

The parent survey was adapted from a survey that was used as part of standard practice by Common Threads for program evaluation. The survey was designed to assess parents' perception of the effect of the program on their children's knowledge, attitudes, and behaviors related to nutrition and cooking. Additional items assessed parents' attitude toward meal time and confidence in being able to prepare healthy meals (Table 3). The items in the parent sur-

Table 1. Overview of After-School Cooking and Nutrition Curriculum for Students Grades 3-8

\begin{tabular}{|c|c|c|c|}
\hline $\begin{array}{l}\text { Lesson } \\
\text { No. }\end{array}$ & $\begin{array}{c}\text { Nutrition Topic } \\
\text { (Learning }^{\text {Objective) }}\end{array}$ & $\begin{array}{c}\text { Cooking Topic } \\
\text { (Learning }^{\text {Objective) }}\end{array}$ & $\begin{array}{c}\text { Cultural } \\
\text { Awareness } \\
\text { Topic }^{c}\end{array}$ \\
\hline 1 & $\begin{array}{l}\text { Composition of healthy } \\
\text { meal (half the plate to } \\
\text { be filled with fruits and } \\
\text { vegetables, quarter } \\
\text { with lean protein, } \\
\text { quarter whole grain) }\end{array}$ & $\begin{array}{l}\text { Safety and sanitation } \\
\text { (wash hands before } \\
\text { cooking and eating; } \\
\text { do not cross- } \\
\text { contaminate) }\end{array}$ & US \\
\hline 2 & $\begin{array}{l}\text { Fruits and vegetables } \\
\text { (understand health } \\
\text { benefits) }\end{array}$ & $\begin{array}{l}\text { Knife skills (ability to } \\
\text { use a knife safely } \\
\text { to plank, dice, } \\
\text { chop, and mince) }\end{array}$ & Mexico \\
\hline 3 & $\begin{array}{l}\text { Protein (identify foods } \\
\text { that contain protein } \\
\text { and understand health } \\
\text { benefits) }\end{array}$ & $\begin{array}{l}\text { Marinating (ability to } \\
\text { use a blender and } \\
\text { marinate) }\end{array}$ & Peru \\
\hline 4 & $\begin{array}{l}\text { Whole grains (identify } \\
\text { whole grain, sources } \\
\text { of whole grains, } \\
\text { understand health }\end{array}$ & $\begin{array}{l}\text { Simmering (ability to } \\
\text { simmer and why } \\
\text { sauces are reduced } \\
\text { with simmering) }\end{array}$ & Italy \\
\hline
\end{tabular}

\begin{tabular}{cccc}
5 & $\begin{array}{c}\text { Composition of healthy } \\
\text { meal (eat a variety of } \\
\text { colorful fruits and } \\
\text { vegetables) }\end{array}$ & $\begin{array}{c}\text { How to read a recipe } \\
\text { (ingredient assembly, } \\
\text { measuring, and } \\
\text { mixing) }\end{array}$ & Senegal \\
\hline 6 & $\begin{array}{c}\text { Fats (reasons and } \\
\text { techniques to lower fat } \\
\text { intake) }\end{array}$ & $\begin{array}{l}\text { Making bread (ability } \\
\text { to make bread } \\
\text { dough) }\end{array}$ & Greece
\end{tabular}

7 Sugar (understand Seasoning (ability to India negative effects of use spices to sugar consumption increase enjoyment and healthy drink of food) options)

8 Reading nutrition labels Sautéing (ability China (understand and make to sauté) decisions based on food label)

\begin{tabular}{|c|c|c|c|}
\hline 9 & $\begin{array}{l}\text { Complete proteins } \\
\text { (combining grain and } \\
\text { legume to get } \\
\text { complete protein) }\end{array}$ & Baking (ability to bake) & Haiti \\
\hline 10 & $\begin{array}{l}\text { Review (reinforce } \\
\text { concepts taught in } \\
\text { lessons 1-9) }\end{array}$ & $\begin{array}{l}\text { Varies (review } \\
\text { techniques used in } \\
\text { Kid's Choice menu) }\end{array}$ & $\begin{array}{l}\text { Kid's Choice } \\
\text { (review country } \\
\text { chosen by kids } \\
\text { to furnish recipes) }\end{array}$ \\
\hline
\end{tabular}

${ }^{a}$ All nutrition lessons reviewed the composition of a healthy meal; ${ }^{b}$ All culinary lessons included the preparation of a well-balanced meal containing fruits and/or vegetables; 'All cultural awareness lessons included background on the cuisine, etiquette, and customs of the country with the objective of attaining awareness and acceptance of other cultures by students.

vey were not designed to be combined into scales, so Cronbach $\alpha$ was not calculated.
The pre-program parent survey was included in the student application packet. Parents returned the pre-program 
Table 2. Survey Items and Scales Used for Pre- and Post-Assessment of After-School Cooking Program for Students Grades 3-8

\section{Items and Scales}

(no. items)

\section{Response Options (Scoring)}

\section{Source}

Measures of nutrition knowledge, food preferences, attitudes, and behaviors

\begin{tabular}{|c|c|c|}
\hline $\begin{array}{l}\text { With what should you fill } \\
\text { half your plate? (1) }\end{array}$ & $\begin{array}{l}\text { Fruits and vegetables }(1) \\
\text { Protein }(0) \\
\text { Grain }(0)\end{array}$ & Original item developed for this survey \\
\hline $\begin{array}{l}\text { Fruits and vegetables } \\
\text { exposed to and liking } \\
\text { for }(14)^{a}\end{array}$ & $\begin{array}{l}\text { I have never tasted this (0) } \\
\text { Do not like (1) } \\
\text { Like a little (2) } \\
\text { Like a lot (3) }\end{array}$ & $\begin{array}{l}\text { Original items developed for this survey } \\
\text { Cronbach } \alpha=.9\end{array}$ \\
\hline $\begin{array}{l}\text { Number of times } \\
\text { vegetables were } \\
\text { consumed } \\
\text { yesterday (1) }\end{array}$ & $\begin{array}{l}\text { Did not eat (1) } \\
\text { Ate } 1 \text { time (2) } \\
\text { Ate } 2 \text { times (3) } \\
\text { Ate } \geq 3 \text { times (4) }\end{array}$ & $\begin{array}{l}\text { Adapted from CATCH Kids Club After School Student } \\
\text { Questionnaire } \\
\text { Reported as item }\end{array}$ \\
\hline $\begin{array}{l}\text { Number of times fruit was } \\
\text { consumed } \\
\text { yesterday (1) }\end{array}$ & $\begin{array}{l}\text { Did not eat (1) } \\
\text { Ate } 1 \text { time (2) } \\
\text { Ate } 2 \text { times (3) } \\
\text { Ate } \geq 3 \text { times (4) }\end{array}$ & $\begin{array}{l}\text { Adapted from CATCH Kids Club After School Student } \\
\text { Questionnaire } \\
\text { Reported as item }\end{array}$ \\
\hline $\begin{array}{l}\text { Number of times chips } \\
\text { were consumed } \\
\text { yesterday (1) }\end{array}$ & $\begin{array}{l}\text { Did not eat (1) } \\
\text { Ate } 1 \text { time (2) } \\
\text { Ate } 2 \text { times (3) } \\
\text { Ate } \geq 3 \text { times (4) }\end{array}$ & $\begin{array}{l}\text { Adapted from CATCH Kids Club After School Student } \\
\text { Questionnaire } \\
\text { Reported as item }\end{array}$ \\
\hline $\begin{array}{l}\text { Number of times soda or } \\
\text { sports drink was } \\
\text { consumed } \\
\text { yesterday (1) }\end{array}$ & $\begin{array}{l}\text { Did not eat (1) } \\
\text { Ate } 1 \text { time (2) } \\
\text { Ate } 2 \text { times (3) } \\
\text { Ate } \geq 3 \text { times (4) }\end{array}$ & $\begin{array}{l}\text { Original item developed for this survey } \\
\text { Reported as item }\end{array}$ \\
\hline $\begin{array}{l}\text { Willingness to try new } \\
\text { foods (4) }\end{array}$ & $\begin{array}{l}\text { Never true (1) } \\
\text { Sometimes true (2) } \\
\text { Usually true (3) } \\
\text { Always true (4) }\end{array}$ & $\begin{array}{l}\text { Adapted from National Heart, Lung, and Blood Institute } \\
\text { Hearts N' Parks Adolescent Performance } \\
\text { Questionnaire } \\
\text { Cronbach } \alpha=.7\end{array}$ \\
\hline \multicolumn{3}{|c|}{ Measures of cooking self-efficacy, knowledge, and interest } \\
\hline Cooking self-efficacy (6) & $\begin{array}{l}\text { I cannot do this (1) } \\
\text { I am not sure I can do this (2) } \\
\text { I can do this with help (3) } \\
\text { I can do this on my own (4) }\end{array}$ & $\begin{array}{l}\text { Adapted from Cooking With Kids Survey }{ }^{26} \\
\text { Cronbach } \alpha=.8\end{array}$ \\
\hline $\begin{array}{l}\text { Frequency of adult } \\
\text { cooking at } \\
\text { home (1) }\end{array}$ & $\begin{array}{l}\text { Never (1) } \\
\text { Once in a while (2) } \\
\text { A few times a week (3) } \\
\text { Every night or almost every night (4) }\end{array}$ & Original items developed for this survey \\
\hline $\begin{array}{l}\text { Frequency of student } \\
\text { helping cook dinner at } \\
\text { home (1) }\end{array}$ & $\begin{array}{l}\text { Never (1) } \\
\text { Once in a while (2) } \\
\text { A few times a week (3) } \\
\text { Every night or almost every night (4) }\end{array}$ & Original items developed for this survey \\
\hline
\end{tabular}

\footnotetext{
${ }^{a}$ Of the 14 items, 8 were fruits or vegetables included in meals cooked by children during the course.
}

survey to Common Threads staff when they enrolled their child in the program. Administration of the postprogram survey varied. Parents were asked to complete a paper survey on the last day of the class when they were invited to eat a meal prepared by their child. If post-surveys were not completed at that time, a followup telephone survey was administered after the last class. Paper and telephone parent surveys consisted of identical questions. The proportion of parents assessed by paper or telephone survey was not recorded. Parents of children participating in fall semester were resurveyed by telephone 6 months after the end of the program. Resource constraints did not permit the 6-month resurvey of parents of children participating in the spring semester. 
Table 3. Survey Items Used for Pre- and Post-Assessment of Parents of AfterSchool Cooking Program Participants Grades 3-8

\section{Family Food Practices: How Often/How Many Times During a Typical Week ...}

Talk about eating healthy foods with child

Child asks to go with you to grocery store

\section{Sit down to eat with child

Sit dow to eat with child \\ Child helps prepare dinner \\ Value of Mealtime and Cooking Confidence}

Response Options (Scoring)

Never (1)

Once in a while (2)

Once or twice a month (3)

At least once a week (4)

Almost every day (5)

Never (1)

Once in a while (2)

About 1 out of 3 times (3)

About half the time (4)

Almost every time I go (5)

Never (1)

1 or 2 times (2)

3-5 times/wk (3)

6 or 7 times/wk(4)

Never (1)

Once in a while (2)

About 1 out of 3 times (3)

About half the time (4)

Almost all the time (5)
Sitting down to dinner with my family is important

I have knowledge and skills to prepare healthy
meals for my family

\section{Strongly disagree (1) \\ Disagree (2) \\ Agree (3) \\ Strongly agree (4)

Strongly disagree (1)
Disagree (2)
Agree (3)
Strongly agree (4)

Only students who completed both pre- and post-surveys were included in the analysis. Responses to survey questions were scored as noted in Table 2. Exposure to new foods was calculated from the number of students who responded "I have never tasted this" for each of the 14 fruit and vegetable liking questions. Scores for all students were averaged for reporting. Percentages in Table 4 may not sum to 100 owing to rounding. Pre- and post-scores $( \pm \mathrm{SD})$ are presented in Tables 5 and 6 . For analysis, change scores were calculated from the difference between pre- and post-scores for each student. The mean change score for multi-item scales was calculated for each student by subtracting the mean pre-score on the scale from the mean post-score. Changes from pre- to post-programming were found to be normally distributed by histogram and quantile-quantile plots. Change scores were analyzed with paired $t$ test except as noted subsequently (SAS version 9.4, SAS Institute, Inc, Cary, NC, 2013) Only differences with $P<.05$ were considered statistically significant.

\section{RESULTS}

\section{Demographics}

Of the 462 students who applied to participate in the program (applicants), 271 completed both pre- and postsurveys and were included in the analysis (analyzed). Both students who applied and those included in the analysis were predominantly female (66\% applicants and $65 \%$ analyzed) and African American or Hispanic (91\% applicants and $86 \%$ analyzed) (Table 4). Most
(84\% applicants and 89\% analyzed) participants were in elementary school. Almost all (94\%) were economically disadvantaged, as judged from eligibility for free or reduced-price lunch.

\section{Student Outcomes}

Participation in the course increased the score for vegetable consumption by about $0.2(P<.005)$ and the score for fruit consumption fruit by 0.23 $(P<.001)$ (Table 5). In addition, participation increased the mean score for nutrition knowledge from 0.6 to $0.8(P<.05)$. The programming also increased exposure to new foods by an average of 1 new food item ( $P$ $<$.001) but it did not significantly affect student liking for fruits and vegetables and it slightly reduced willingness to try new foods $(P<.05)$.

Participation in the cooking education program increased students' cooking self-efficacy score by $0.4(P<.001)$ (Table 5) and the frequency of student cooking at home score by $0.1(P<.05)$. Participation in the program did not affect the consumption of chips or soda, or the frequency with which parents or other adults in the household cooked at home.

\section{Parent Outcomes}

The analysis included data from 257 parents who completed both preand post-parent surveys and a subset of parents from the fall semester who were resurveyed 6 months after the end of the program.

Parents reported that their child's participation in the cooking program significantly increased the score for family conversations about healthy food by $0.3(P<.01)$, the score for how often their child prepared dinner by $0.2(P<.05)$, and the score for parents' perception of their own ability to prepare a healthy meal by 0.2 $(P<.001)$ (Table 6$)$. The programming also significantly increased the score for the importance parents place on the family meal by $0.1(P<.01)$. The program did not affect how often the child asked to go grocery shopping or the frequency with which parents sat down for dinner with their child.

The subset of parents whose children were enrolled in the fall semester reported persistent effects of program 
Table 4. Baseline Anthropometric Data for Students Grades 3-8 in After-School Cooking Program (\%)

\begin{tabular}{lcc} 
Variables & Applicants $^{\text {a }} \mathbf{( n = 4 6 2 )}$ & Analyzed $^{\mathbf{a}} \mathbf{( n = 2 7 1 )}$ \\
Age, y & & \\
$\leq 8$ & 15 & 19 \\
9 & 25 & 32 \\
10 & 28 & 26 \\
11 & 16 & 13 \\
12 & 11 & 8 \\
$\geq 13$ & 5 & 3 \\
Missing data & 1 & 1 \\
Gender & & \\
Boy & 34 & 35 \\
Girl & 66 & 65 \\
Ethnicity & & \\
African American & 49 & 44 \\
Hispanic & 42 & 42 \\
White & 5 & 7 \\
Other & 5 & 7 \\
Missing data & 6 & 0 \\
\hline
\end{tabular}

${ }^{a}$ Applicants are students who completed an application to take the course. Analyzed are students who filled out an application, a pre-survey, and a post-survey; ${ }^{\mathrm{b}}$ Missing data indicate the percentage of students who left individual items blank. All other percentages were calculated using non-missing $\mathrm{n}$ as the denominator.

participation (Table 6). Six months after the end of the class, parents reported that children continued to talk about healthy foods and prepared dinner significantly more frequently than before the class. Parents were also more confident in their own ability to prepare a healthy meal 6 months after the course (all $P<.05$ ).

Table 5. Survey Results for Pre- and Post-Assessment of After-School Cooking Program for Students Grades 3-8

Mean (SD)

\begin{tabular}{|lrr|}
$\begin{array}{l}\text { Survey Items or Scales for Fall and Spring Semesters } \\
\text { (n= 271) (Range of Possible Scores) }\end{array}$ & $\begin{array}{c}\text { Before } \\
\text { Program }\end{array}$ & $\begin{array}{c}\text { After } \\
\text { Program }\end{array}$ \\
\hline Ideal proportion of fruits and vegetables on plate (0-1) & $0.6(0.4)$ & $0.8(0.5)^{\mathrm{C}}$ \\
\hline Exposure to fruits and vegetables (0-14) & $11.3(2.9)$ & $12.3(2.4)^{\mathrm{C}}$ \\
\hline Liking for fruits and vegetables (1-3) & $2.4(0.4)$ & $2.4(0.4)$ \\
\hline Vegetable consumption (1-4) & $2.2(1.1)$ & $2.4(1.1)^{\mathrm{b}}$ \\
\hline Fruit consumption (1-4) & $2.3(0.9)$ & $2.5(1.1)^{\mathrm{c}}$ \\
\hline Chip consumption (1-4) & $1.7(0.9)$ & $1.7(0.9)$ \\
\hline Soda consumption (1-4) & $1.6(0.8)$ & $1.6(0.8)$ \\
\hline Willingness to try new foods (1-4) & $3.3(0.7)$ & $3.2(0.8)^{\mathrm{a}}$ \\
\hline Cooking self-efficacy (1-4) & $3.2(0.6)$ & $3.6(0.5)^{\mathrm{c}}$ \\
\hline Adults cook dinner (1-4) & $3.6(0.8)$ & $3.6(0.7)$ \\
\hline Child helps cook dinner (1-4) & $2.5(0.9)$ & $2.6(0.8)^{\mathrm{a}}$ \\
\hline
\end{tabular}

Statistically significant changes assessed by $t$ test indicated by superscripts: ${ }^{\mathrm{a}} P<.05 ;{ }^{\mathrm{b}} P<.01 ;{ }^{\mathrm{c}} P<.001$. program increased nutrition knowledge of, exposure to, and consumption of fruits and vegetables. Students reported that the program enhanced their self-efficacy and participation in cooking. Immediately after the program, parents also reported that having students participate in the program increased the frequency with which children and parents talked about healthy food, the frequency with which children helped cook, and parents' confidence in their own cooking skills. After 6 months, parents of fall semester students retained confidence in their cooking skills and reported that their children still talked about healthy eating and helped prepare dinner at home more often than before the program.

These results are consistent with previous studies of traditional cooking and nutrition education programs that compared the intervention with a control group. A meta-analysis of a wide variety of school-based nutrition education programs found that experiential learning programs such as those that incorporate hands-on cooking and/ or gardening are especially effective in improving nutrition knowledge and vegetable preference or consumption in elementary schoolchildren. ${ }^{28}$ For instance, a program that included tasting new foods and cooking (Cooking with Kids) increased elementary students' preference for vegetables and cooking self-efficacy compared with control students $^{21}$; these effects were especially marked in boys and in children who had not cooked before. ${ }^{29}$ It was also reported that a combined garden and cooking education course (LA Sprouts) attenuated reductions in vegetable intake and reduced BMI z-score compared with control students, ${ }^{30}$ and a cooking education course that provided food to families increased consumption of selected vegetables and participation in cooking compared with control families. ${ }^{20}$ Similarly, a nutrition and cooking education program offered to parent-child dyads (Healthy Home Offerings via the Mealtime Environment) significantly increased food preparation skills in children compared with a control group. ${ }^{23}$ The Common Threads program increased consumption of fruits and vegetables without providing food to families and led to a persistent (up to 6-month) increase in child involvement in meal preparation.

Demonstrating the practical significance of these results requires additional 
Table 6. Survey Results for Pre-, Post-, and 6-Mo Post-Assessment of Parents of After-School Cooking Program Participants Grades 3-8

\section{Survey Items (Range of Possible Scores)}

Fall and spring semesters $(n=257)$

Child and parent talk about healthy foods (1-5)

Child asks to go with parent to grocery store (1-5)

Parent agrees that sitting down for dinner is important (1-4)

Parent sits down to eat with child (1-4)

Child helps prepares dinner (1-5)

Parent agrees that (s)he has knowledge and skills to make healthy meals (1-4)

\section{Fall semester}

Child and parent talk about healthy foods (1-5)

Child asks to go with parent to grocery store (1-5)

Parent agrees that sitting down for dinner is important (1-4)

Parent sits down to eat with child (1-4)

Child prepares dinner (1-5)

Parent agrees that (s)he has knowledge and skills to make healthy meals (1-4)
Mean (SD)

Before Program

$4.1(1.1)$

After Program

$4.1(1.2)$

$3.8(0.4)$

$3.3(0.7)$

$2.9(1.2)$

$3.5(0.6)$

$4.4(0.9)^{b}$

$4.0(1.2)$

$3.9(0.3)^{b}$

$3.4(0.7)$

$3.1(0.9)^{\mathrm{a}}$

$3.7(0.5)^{\mathrm{c}}$

Before Program $(n=147)$

6 Mo After Program $(n=128)$

$\begin{array}{ll}4.2(1.1) & 4.5(0.9)^{\mathrm{a}} \\ 4.0(1.3) & 4.1(1.3) \\ 3.8(0.4) & 3.9(0.3) \\ 3.4(0.7) & 3.5(0.6) \\ 2.8(1.2) & 3.2(0.9)^{\mathrm{a}} \\ 3.5(0.5) & 3.7(0.5)^{\mathrm{a}}\end{array}$

$4.5(0.9)^{\mathrm{a}}$

$3.9(0.3)$

$3.5(0.6)$

$3.7(0.5)^{a}$

Statistical significance assessed by $t$ test denoted by superscripts: ${ }^{\mathrm{a}} P<.05 ;{ }^{\mathrm{b}} P<.01{ }^{\mathrm{c}} P<.001$.

measures to link survey results to reliable measures of diet quality, which were beyond the scope of this program evaluation. The survey questions used in this study queried the number of times students ate fruits or vegetables on the previous day, rather than asking students to estimate the number of cups or servings consumed. ${ }^{25}$ For context, the effect sizes seen in this program evaluation were compared with pre-post differences reported for studies conducted in controlled research settings. $^{20,21,30,31}$ This is limited by differences in survey instruments, analysis, and reporting among publications. To the extent that it could be estimated, the current authors found that the effects on nutrition knowledge, self-efficacy for cooking skills, and vegetable consumption seen in this communitybased program were similar to those seen in research settings. In contrast, the effect sizes for children cooking at home were smaller than those reported in research settings.

It is also interesting to note the specificity of the reported effects. The program reinforced the importance of fruit and vegetable consumption at every lesson and significantly increased consumption of those foods. In contrast, the program touched only briefly on the reasons to avoid sugar-sweetened beverages and high-fat foods such as snack chips, and did not change consumption of those foods. These data suggest that consistent, repeated reinforcement of lesson components is likely necessary to bring about behavior change.

Increasing both vegetable consumption and cooking skills in children should improve diet quality, because it has been found that vegetables prepared at home are lower in fat and salt than those prepared away from home (eg, in restaurants). ${ }^{9}$ A recent review summarized evidence that more frequent family meals are associated with greater consumption of fruits, vegetables, grains, and calcium-rich foods and reduced risk of unhealthy eating patterns. ${ }^{7}$ It has been shown that an intervention reducing the intake of food consumed away from home improved diet quality and body composition in overweight children. $^{32}$

Higher diet quality scores are independently associated with improved weight status in elementary schoolchildren, ${ }^{33}$ and a recent meta-analysis showed that dietary patterns high in energy and fat and low in fiber are predictive of later obesity. ${ }^{3}$ These studies suggest that it is reasonable to hypothesize that educational interventions that improve vegetable liking and intakeand lead to improved diet quality- may help students achieve a healthy BMI over time. Indeed, the US Department of Agriculture Fresh Fruit and Vegetable Program was credited with a reduction in childhood obesity rate of $3 \%$ in Arkansas, ${ }^{34}$ and a Comparative Effectiveness Review of interventions to prevent childhood obesity concluded that there was moderate evidence that school-based programs aimed at improving diet could contribute to reducing the obesity rate. ${ }^{35}$ Furthermore, cooking at home may promote increased frequency of family meals; a recent meta-analysis showed that eating meals with family 3 times/wk decreased the risk of overweight in children by $12 \% .^{36}$

Diet-related behaviors are influenced by a combination of biologically determined predispositions, previous experiences with food, attitudes, beliefs, familial and cultural norms, availability, price, time, and skill in preparing foods. ${ }^{37,38}$ Examples of programs that have a lasting impact on diet-related behavior are those that offer children the opportunity to engage with food in a different way-addressing these other factors such as experiential and contextual knowledge and incorporating social networks, including family members. ${ }^{39}$

Exposing children to new and different foods to which they may not have previously had access or exposure 
may address many of the factors that contribute to childhood obesity, according to nutrition theory. ${ }^{38}$ Indeed, after 6 months, parents reported that their children still talked about healthy eating and prepared dinner at home more often than they had before the program. This exposure and attitudinal shift may act as a strong complement to other nutrition and wellness activities going on in schools such as healthy snack policies, healthy celebration policies, and healthier school food options enacted in recent years. ${ }^{40}$

Changes in diet quality, specifically increases in fruit and vegetable consumption, have implications for health, including cardiovascular risk factors. $^{41-43}$ Two implementations of the Dietary Approaches to Stop Hypertension diet in children resulted in increased fruit and vegetable intake and reduced blood pressure. ${ }^{44,45}$ These results suggest that modest changes in fruit and vegetable intake may improve diet quality and health in children and reduce the risk of adult cardiovascular disease even in the absence of changes in BMI.

The experiential cooking and nutrition education program used in the current report improved both cooking selfefficacy and liking and consumption of vegetables. In addition, the program demonstrated an influence on home eating and cooking practices. Over time, the combination of increased preference for vegetables, cooking skills, and the involvement of family in routine home meal practices may contribute to improved health and reduced risk of chronic disease in the students who participated in the program.

More children applied to participate in the program than completed both a pre- and post-survey. The gender, age, and ethnicity of students who applied and those who completed both the pre- and post-surveys were similar. Students who missed either the pre- or post-survey would have received less instruction, and thus the effects of programming in these students would be smaller. The majority of students studied were of low socioeconomic status and it is unknown whether results would apply to students of higher socioeconomic status. School staff selected the students who participated in the program using their own criteria, so the results may not apply to all students in grades 3-8. A control group that does not receive the intervention is needed to estimate true effect sizes.

\section{IMPLICATIONS FOR RESEARCH AND PRACTICE}

It may be possible to increase healthy behaviors such as home cooking, fruit and vegetable intake, and communication within the family about healthy eating in economically disadvantaged students with an experiential cooking and nutrition education course led by chef-instructors. In the context of culinary education, chef-instructors were effective at imparting nutrition knowledge and bringing about behavior change. The program did not require a gardening component or distribution of food to families to be effective at increasing behaviors associated with good nutrition. The program has the potential to work in concert with and in support of other school- and community-based strategies, including those that incorporate gardening and physical activity, to address nutritional health inequities such as obesity and its comorbidities.

\section{ACKNOWLEDGMENTS}

The authors are grateful to ConAgra Foods for funding this evaluation, to Dr Alexandra Evans for critical review of the manuscript, to the school staff and volunteers who facilitated the program, and to the students and parents who participated.

\section{REFERENCES}

1. Kumanyika SK, Swank M, Stachecki J, Whitt-Glover MC, Brennan LK. Examining the evidence for policy and environmental strategies to prevent childhood obesity in black communities: new directions and next steps. Obes Rev. 2014;15(Suppl 4):177-203.

2. Kumanyika SK, Whitt-Glover MC, Haire-Joshu D. What works for obesity prevention and treatment in black Americans? Research directions. Obes Rev. 2014;15(Suppl 4):204-212.

3. Ambrosini GL. Childhood dietary patterns and later obesity: a review of the evidence. Proc Nutr Soc. 2014;73:137-146.

4. Scientific Report of the 2015 Dietary Guidelines Advisory Committee. http:// health.gov/dietaryguidelines/2015-scientific -report/PDFs/Scientific-Report-of-the-2015
-Dietary-Guidelines-Advisory-Committee. pdf. Accessed August 19, 2016.

5. Kim SA, Moore LV, Galuska D, et al. Vital signs: fruit and vegetable intake among children-United States, 20032010. MMWR Morb Mortal Wkly Rep. 2014;63:671-676.

6. Nielsen SJ, Rossen LM, Harris DM, Odgen CL. Fruit and vegetable consumption of U.S. Youth, 2009-2010. NCHS Data Brief; 2014:1-8.

7. Martin-Biggers J, Spaccarotella K, Berhaupt-Glickstein A, Hongu N, Worobey J, Byrd-Bredbenner C. Come and get it! A discussion of family mealtime literature and factors affecting obesity risk. Adv Nutr. 2014;5:235-247.

8. Berge JM, Wall M, Hsueh TF, Fulkerson JA, Larson N, NeumarkSztainer D. The protective role of family meals for youth obesity: 10-year longitudinal associations. J Pediatr. 2015;166: 296-301.

9. Lin $\mathrm{BH}$, Wendt M, Guthrie JF. Impact on energy, sodium and dietary fibre intakes of vegetables prepared at home and away from home in the U.S.A. Public Health Nutr. 2013;16:1937-1943.

10. Guthrie JF, Lin BH, Frazao E. Role of food prepared away from home in the American diet, 1977-78 versus 199496: changes and consequences. J Nutr Educ Behav. 2002;34:140-150.

11. Centers for Disease Control and Prevention. Children's Food Environment State Indicator Report. http://www.cdc.gov/ obesity/downloads/childrensfoodenviron ment.pdf. Accessed August 19, 2016.

12. Ranjit N, Evans AE, Springer AE, Hoelscher DM, Kelder SH. Racial and ethnic differences in the home food environment explain disparities in dietary practices of middle school children in Texas. J Nutr Educ Behav. 2015;47:53-60.

13. Couch SC, Glanz K, Zhou C, Sallis JF, Saelens BE. Home food environment in relation to children's diet quality and weight status. J Acad Nutr Diet. 2014; 114:1569-1579.e1.

14. Trofholz AC, Tate AD, Draxten ML, Neumark-Sztainer D, Berge JM. Home food environment factors associated with the presence of fruit and vegetables at dinner: a direct observational study. Appetite. 2016;96:526-532.

15. Kunin-Batson AS, Seburg EM, Crain AL, et al. Household factors, family behavior patterns, and adherence to dietary and physical activity guidelines among children at risk for obesity. J Nutr Educ Behav. 2015;47: 206-215. 
16. Gross SM, Pollock ED, Braun B. Family influence: key to fruit and vegetable consumption among fourth- and fifthgrade students. I Nutr Educ Behav. 2010;42:235-241.

17. Lakkakula AP, Zanovec M, Silverman L, Murphy E, Tuuri G. Black children with high preferences for fruits and vegetables are at less risk of being at risk of overweight or overweight. J Am Diet Assoc. 2008;108:1912-1915.

18. Wolfson JA, Bleich SN. Fruit and vegetable consumption and food values: national patterns in the United States by Supplemental Nutrition Assistance Program eligibility and cooking frequency. Prev Med. 2015;76:1-7.

19. Nicklas TA, Jahns L, Bogle ML, et al. Barriers and facilitators for consumer adherence to the dietary guidelines for Americans: the HEALTH study. J Acad Nutr Diet. 2013;113:1317-1331.

20. Chen Q, Goto K, Wolff C, BiancoSimeral S, Gruneisen K, Gray K. Cooking up diversity. Impact of a multicomponent, multicultural, experiential intervention on food and cooking behaviors among elementary-school students from lowincome ethnically diverse families. Appetite. 2014;80:114-122.

21. Cunningham-Sabo L, Lohse B. Cooking with Kids positively affects fourth graders' vegetable preferences and attitudes and self-efficacy for food and cooking. Child Obes. 2013;9:549-556.

22. Hersch D, Perdue L, Ambroz T, Boucher JL. The impact of cooking classes on food-related preferences, attitudes, and behaviors of school-aged children: a systematic review of the evidence, 20032014. Prev Chronic Dis. 2014;11:1-10.

23. Fulkerson JA, Rydell S, Kubik MY, et al. Healthy Home Offerings via the Mealtime Environment (HOME): feasibility, acceptability, and outcomes of a pilot study. Obesity (Silver Spring). 2010;18(suppl 1):S69-S74.

24. Walker L, Jarpe-Ratner E, Meehan P. Building a base of evidence for Common Threads, a promising school-based nutrition education program that fits the new SNAPEd guidance. Baltimore, MD: National Association of Welfare research statistics meeting; 2012. http://nawrs.org/ baltimore2012/presentations/SNAP Ed_Walker_Jarpe-Ratner.pdf. Accessed August 19, 2016.

25. The University of Texas-Houston Health Sciences Center CATCH Kids Club After-School Student Question- naire. http://catchinfo.org/wp-content/ uploads/2014/11/ASSQ-CKC-AFTER -SCH-QNNE-final.pdf. Accessed August 19, 2016.

26. Lohse B, Cunningham-Sabo L, Walters LM, Stacey JE. Valid and reliable measures of cognitive behaviors toward fruits and vegetables for children aged 9 to 11 years. J Nutr Educ Behav. 2011;43:42-49.

27. National Heart, Lung, and Blood Instititute and National Recreation and Park Association. Hearts N’ Parks Community Mobilization Guide. Bethesda, MD: National Institutes of Health Publication No. 01-1655, 2001.

28. Dudley DA, Cotton WG, Peralta LR. Teaching approaches and strategies that promote healthy eating in primary school children: a systematic review and meta-analysis. Int J Behav Nutr Phys Act. 2015;12:28

29. Cunningham-Sabo L, Lohse B. Impact of a school-based cooking curriculum for fourth-grade students on attitudes and behaviors is influenced by gender and prior cooking experience. J Nutr Educ Behav. 2014;46:110-120.

30. Gatto NM, Martinez LC, SpruijtMetz D, Davis JN. LA sprouts randomized controlled nutrition and gardening program reduces obesity and metabolic risk in Latino youth. Obesity (Silver Spring). 2015;23:1244-1251.

31. Davis JN, Martinez LC, SpruijtMetz D, Gatto NM. LA Sprouts: a 12-week gardening, nutrition, and cooking randomized control trial improves determinants of dietary behaviors. J Nutr Educ Behav. 2016;48:2-11.e1.

32. Altman M, Cahill Holland J, Lundeen D, et al. Reduction in food away from home is associated with improved child relative weight and body composition outcomes and this relation is mediated by changes in diet quality. J Acad Nutr Diet. 2015; 115:1400-1407.

33. Jennings A, Welch A, van Sluijs EM, Griffin SJ, Cassidy A. Diet quality is independently associated with weight status in children aged 9-10 years. J Nutr. 2011;141:453-459.

34. Qian Y, Nayga RM Jr, Thomsen MR, Rouse HL. The effect of the Fresh Fruit and Vegetable Program on childhood obesity. Appl Econ Perspect Pol. 2016; 38:260-275.

35. Wang Y, Wu Y, Wilson RF, et al. Childhood obesity prevention programs: comparative effectiveness review and meta-analysis.
AHRQ Comparative Effectiveness Reviews. Rockville, MD: Agency for Healthcare Research and Quality (US); 2013. Report No. 13-EHC081-EF.

36. Hammons AJ, Fiese BH. Is frequency of shared family meals related to the nutritional health of children and adolescents? Pediatrics. 2011;127:e1565-e1574.

37. Baranowski T, Cullen KW, Nicklas T, Thompson D, Baranowski J. Are current health behavioral change models helpful in guiding prevention of weight gain efforts? Obes Res. 2003;11(suppl):23S-43S.

38. Contento IR. Nutrition education: linking research, theory, and practice. Asia Pac J Clin Nutr. 2008;17(suppl 1):176-179.

39. Liquori T, Koch PD, Contento IR, Castle J. The Cookshop program: outcome evaluation of a nutrition education program linking lunchroom food experiences with classroom cooking experiences. J Nutr Educ. 1998;30:302-313.

40. Child Nutrition and WIC Reauthorization Act of 2004. Section 204 of Public Law 108-265-June 30, 2004. http:// www.fns.usda.gov/sites/default/files/ 108-265.pdf. Accessed August 23, 2016.

41. Jääskeläinen P, Magnussen CG, Pahkala K, et al. Childhood nutrition in predicting metabolic syndrome in adults: the cardiovascular risk in Young Finns Study. Diabetes Care. 2012;35:1937-1943.

42. Aatola H, Koivistoinen T, HutriKähönen N, et al. Lifetime fruit and vegetable consumption and arterial pulse wave velocity in adulthood: the Cardiovascular Risk in Young Finns Study. Circulation. 2010;122:2521-2528.

43. Moore LL, Bradlee ML, Singer MR, Qureshi MM, Buendia JR, Daniels SR. Dietary Approaches to Stop Hypertension (DASH) eating pattern and risk of elevated blood pressure in adolescent girls. Br J Nutr. 2012;108:1678-1685.

44. Saneei P, Hashemipour M, Kelishadi R, Rajaei S, Esmaillzadeh A. Effects of recommendations to follow the Dietary Approaches to Stop Hypertension (DASH) diet v. usual dietary advice on childhood metabolic syndrome: a randomised cross-over clinical trial. $\mathrm{Br}$ J Nutr. 2013;110:2250-2259.

45. Novotny R, Nigg CR, Li F, Wilkens LR. Pacific kids DASH for health (PacDASH) randomized, controlled trial with DASH eating plan plus physical activity improves fruit and vegetable intake and diastolic blood pressure in children. Child Obes. 2015;11:177-186. 
705.e1 Jarpe-Ratner et al

CONFLICT OF INTEREST

Neilé Edens, Stephanie Folkens, and Sonika Sharma are employees of Com-
Journal of Nutrition Education and Behavior • Volume 48, Number 10, 2016

mon Threads. The other authors have not stated any conflicts of interest. 